GRAPHICAL HYDRAULICS.

Water Pipe and Sewer Discharge Diagrams. By T. C. Ekin. Pp. 21 . (London: Archibald Constable and Co., Ltd., I908.) Price 12s. 6d. net.

$\mathrm{O}^{\mathrm{F}}$ all empirical formulæ devised for the solution of practical problems in natural science, hydraulic formulæ are perhaps the most involved and complex, and of all hydraulic formulæ it is doubtful whether there be a more formidable expression than the coefficient in Ganguillet and Kutter's formula for the flow of water in pipes and channels.

The general expression, and that which is now commonly recognised as furnishing the most trustworthy basis for the estimation of current velocity in such cases, is the equation devised by Chezy towards the close of the eighteenth century, viz. $\mathrm{V}=\mathrm{C} \sqrt{\mathrm{RS}}$, involving the hydraulic mean depth $(R)$ and the sine of the slope $(\mathrm{S})$ in conjunction with a coefficient $\mathrm{C}$.

As determined by the classical researches of Ganguillet and Kutter (the formula is more generally associated with the name of the latter only of the two eminent Swiss experimentalists), the coefficient takes
the form:-

$$
\mathrm{C}=\left[\frac{a+\frac{l}{n}+\frac{m}{\mathrm{~S}}}{\mathrm{I}+\left(a+\frac{m}{\mathrm{~S}}\right) \frac{n}{\sqrt{ } \mathrm{R}}}\right]
$$

in which $a, l$, and $m$ are respectively in English units, $4 I^{\circ} 660475, x^{\circ} 8 I_{325}$, and 0.0028075 , and $n$ is a variable depending upon the degree of roughness of the surface.

The labour involved in working out casually, and as necessity arises, a particular value from so cumbrous an expression is sufficiently obvious, and it is not surprising that a number of attempts have been made to supply some ready solution applicable to different data by the construction of curves and graphical
diagrams.

The author points out that hitherto such curves have not dealt with gradients exceeding 5 per Iooo, and that steeper gradients are often required. He has, therefore, worked out a series of curves giving the discharges of pipes ranging from 3 to 48 inches in diameter, and the velocities, when running full, on gradients from 5.28 feet per mile, I in 1000 or I per Iooo, up to $79^{\circ} 2$ feet per mile, I in 66.6 or 15 per 1000 , and embodied the results in four large diagrams in which each discharge curve is the result of twentytwo separate calculations, and each velocity curve has been calculated for each point in which it cuts the discharge curve.

These diagrams are not strictly derived from Kutter's original formula, but from Flynn's modified statement of it, with $n$ and $\mathrm{S}\left(=0^{\circ} \circ \mathrm{o}\right)$ taken as constant throughout the series of curves, and $\sqrt{R}$ varying with each diameter of pipe. The coefficient of roughness of surface $(n)$ has been fixed at $0^{\circ} 0_{3}$, as most applicable to practical work under ordinary conditions. There are a number of cases, however, in which pipes calculated with this value give results either too large or too small, and with the view of making the diagrams apply to several coefficients of roughness, the author has calculated a series of constants, embidied in a separate table. There are six tables in all form- ing an appendix, yielding detailed information respecting pipe flow and hydraulic data generally.

The compilation should prove of great utility to those engaged upon problems of water supply, sewage disposal, and practical problems of a kindred nature.

\section{BRITISH OAK GALLS.}

British Oak Galls. By E. T. Connold. Pp. xviii + 169; 68 plates. (London: Adlard and Son, r9o8.) Price ros. $6 d$. net.

M R: E. T. CONNOLD has already given us a I very valuable work on "British Vegetable Galls," but in that work, as the author states in the preface, the galls of the oak are not included, as he intended to publish a separate book dealing with them. This book has now appeared, and in every way it comes up to the standard of the larger work. A great feature of the book is the many life-like and excellently reproduced photographs of actual specimens of galls.

The oak is the abode of some five hundred different species of insects and other animals which subsist mainly on the leaves. Some are parasitic on the larvæ of the gall makers, and others are inquilines, which subsist on the tissues of the galls.

In his introduction the author touches upon some historical matters, and in chapter i. several very interesting and at present not fully understood phenomena in connection with the formation and colours of galls are discussed. Chapter ii., which deals with the characteristics of oak-gall growth, such as position, duration of growth, variations in shape, size and colour, \&c., is also a very interesting chapter to the student of oak galls.

Chapters iii. and iv. deal respectively with the numerical aspect of oak galls and the Cynipidæ affecting the oak. The latter chapter is intended to present in a concise form such information as may be necessary for the collector or student who may not have ready access to other books which deal with these interesting and remarkable insects.

Chapter v. gives a short description of the genus Quercus, and especially of the British oak. In chapter vi. many useful hints on the collecting and mounting of oak galls are given. The rest of the book deals individually with the various species which cause oak galls. A synoptical table is given, also a table of the months in which the galls jllustrated in the book may be found. A list of midEuropean oak galls, with brief characteristics and position the gall occupies on the tree, is added, and will prove a great help to many. A useful index is also included.

This volume, the author tells us, is the outcome of fifteen years' study and practical research in the field. He is glad to say that he has been able to describe several galls not mentioned in any other English publication. Still, in spite of this great amount of time and study, the author does not claim completeness for his work. In the preface he says:-

" There is much more to be ascertained concerning the growth of oals galls, and one purpose of the

NO. 2049, VOL. 79] 